\title{
Volatility Spillovers of Sharia Index during the Covid-19 Pandemic in ASEAN
}

\author{
Suripto $^{\mathbf{a}^{*}}$ \\ ${ }^{a}$ Department of Business Administration, Lampung University, Indonesia \\ C H R O N I C L E \\ Article history: \\ Received: April 12, 2021 \\ Received in revised format: April \\ 27, 2021 \\ Accepted: May 27, 2021 \\ Available online: May 27, 2021 \\ Keywords: \\ Volatility spillovers \\ Covid-19 \\ EGARCH \\ ASEAN
}

\section{Introduction}

A strong and efficient stock market in the long term conceptually refers to the anomaly that undermines the accuracy of the efficient market hypothesis. In practice, various forms of market anomalies undermine its accuracy, thereby, leading to inefficiency, such as herding behavior. Investors herd when they imitate the movements of others. This conduct happens when there is a non-stop interplay between rational investors, which prevents them from looking for data on market fundamentals, which is influenced by utilizing volatility spillovers (Fahdiansyah, 2016). According to Ady et al. (2010), the higher the information imbalance among market players, the bigger the spread. Furthermore, the stronger the capital market's competition, the lower the selling price and the higher the buying price, thereby leading to a smaller spread. International finance integration has improved significantly over the past 30 years, thereby facilitating stronger cross-border mobility of capital and volatile spillovers (Billio et al., 2017), Dean et al. (2010) stated that increasing international financial integration led to a rise in the relationship between stock market returns and international market volatility. However, most influential research tends to focus on developed monetary contexts when the inventory market is at a mature stage. The Volatility Spillovers of Sharia Index for the duration of the Covid-19 Pandemic in ASEAN looks pretty under-explored in the cutting-edge literature. During the Covid-19 pandemic, the Sharia principles were the basis for Muslim investor's behavior in the Islamic capital market (Sugianto et al., 2020; Suripto, 2021). The Islamic economy's role in overcoming the economic crisis during the pandemic is one of the most important strategies for survival (Arfah et al., 2020). However, several stock indexes in the housing sector increased during this period, which means that several investment alternatives were developed during the pandemic (Levent \& Beliz, 2020). Mahata et al. (2020) stated that there are still stocks with large cash flow irrespective of the pandemic as an investment option. Therefore, this research aims to determine the Volatility Spillovers of Sharia Index during the Covid-19 Pandemic in ASEAN. This is the first research carried out to analyze the effect of the Volatility Spillovers of Sharia Index during the pandemic, which is different from previous studies that only analyzed non-Sharia Volatility

* Corresponding author. Tel.: +81334618878

E-mail address: suriptob.1969@fisip.unila.ac.id (Suripto)

(C) 2021 by the authors; licensee Growing Science, Canada. doi: $10.5267 /$ j.ijdns.2021.5.009 
Spillovers' effects in ASEAN. Various literature studies center attention on supplying a deeper perception of the inventory market's volatility due to the fact it indicates the threat and uncertainty of economic belongings (Gunarto et al., 2020). Volatility Spillovers refer to risky modifications in one market that create a lagging and have an impact on different inventory markets' volatility (Milunovich \& Thorp, 2006; Aggarwal et al., 1999). They are applicable for hazard management, and, therefore, it is vital to discover the sources of volatility in monetary markets around the world. Generally, the immoderate economic and fairness market volatilities are hazardous to the financial machine characteristic (Nikmanesh \& Mohd Nor, 2016). This lookup investigates the Volatility Spillovers of Sharia Index for the duration of the Covid-19 Pandemic in ASEAN. Furthermore, it controls the structural damage in the stock return series and focuses on the US market spillovers to the stock of ASEAN countries. The EGARCH approach was used to obtain daily frequency data set from March 2020 to December 31, 2020, during the Covid-19 Pandemic.

This research is motivated from several perspectives. The first is investigating volatility spillovers in emerging markets during the Covid-19 Pandemic. Due to the younger nature of these markets, they are more prone to even minor adjustments than the developed ones. Furthermore, this lookup is additionally influenced through the several literature portions that do not now persuade the volatility spillovers throughout the pandemic. According to Carrieri et al. (2007), it is necessary to think about the volatility spillovers from extraordinary views due to the fact preceding lookup has proven that economic and macroeconomic tendencies and monetary liberalization insurance policies play a vital function in integrating rising markets. Another important motivation associated with this research is the trend of increasing worldwide monetary integration of the Islamic index to 6 international locations in ASEAN for the duration of the Covid-19 pandemic. For example, (Batten et al., 2019) documented the essential elements of Asian inventory markets and their relation to US inventory markets. (Miyakoshi, 2003) mentioned that volatility is extra influenced with the aid of the region's influential inventory market (Japan) than the US. Meanwhile, John Wei et al. (1995) and Suripto (2021a, 2021b) mentioned that the US inventory market has a greater impact on Asian fairness markets. Therefore, it is vital to grant extra proof to provide also perception into the volatility spillover puzzle between the US and different Asian inventory markets. In an influential study, Diebold Kamil Yilmaz et al. (2008) delivered specific measures of return and volatility spillover. This lookup reviews putting proof of conflicting behavior in the dynamics of returns and volatility spillover. More specifically, the stock's return spillovers exhibit a slowly growing vogue without bursts, whilst the volatility spillover suggests no fashion with clear bursts.

This study adds to the literature by imparting an evaluation of the effect of shocks originating from developed international locations on creating ASEAN inventory markets. This lookup advances until now posted research of volatility spillovers in several fields. Firstly, it focuses on the context of the ASEAN inventory market, which is highly poorly explored. Secondly, it is amongst the first research to analyze volatility spillover outcomes with the ICSS algorithm used to discover severe breaks in ASEAN inventory markets (Sharma, 2021).

This research has sturdy realistic relevance and coverage implications that entice policymakers and investors. Furthermore, it is necessary to analyze the volatility spillover for worldwide funding and diversification. A clear appreciation of the worldwide volatility spillover is imperative for monetary supervisors to forestall home fairness markets' excessive.

\section{Theoretical foundation}

\subsection{Volatility Spillovers}

Volatility Spillovers are the tendency for volatility to alternate in one market or asset following modifications in volatility in distinctive markets. This implies the quick action of facts by way of a sequence of brief volatility changes throughout a couple of markets. Volatility publicity is extremely good from volatility spillover. According to him, volatility spillover focuses on the possible effect of a volatility shock in one market on volatility in different markets in a rapid duration of time. Meanwhile, volatility publicity or volatility beta can trap long-term relationships. This class places extra emphasis on the spillover created from immoderate interdependence between the economies of greater than a few countries. The means of interdependence here is a shock that is transferred between international locations due to the fact of genuine hyperlinks and economic links. Of course, in the spillover analysis, there is a transmission mechanism in the swap of information, every exceptional and horrible information. Of course, data that strikes from one market to some other is treasured information. King Wadhani (1990) argues that facts that have been posted from one market to some different will have an effect on the entire market at the same time, then again, of course, the widespread have an impact on the information that can be specified between markets.

\subsection{Model development}

Literature review relating to capital markets, especially those related to the integration and spillover between capital markets. This research is conducted between the stock market within an area and between regions. Research on the spillover effect becomes interesting when there is an event that causes volatility. During the Covid pandemic, the behavior of Muslim investors in the Islamic capital market which is the basis for investing is the principle of sharia (Sugianto et al., 2020). The role of the Sharia economy in overcoming the economic crisis during the pandemic is one of the most important strategies 
to survive (Arfah et al., 2020). Even during the pandemic, it turns out that several stock indexes in the housing sector have increased (Levent \& Beliz, 2020). This means that during the pandemic there are several investment alternatives. During the pandemic, there are still stocks that have large cash flow as an investment option (Mahata et al., 2020). There has been an abundance of asymmetric volatility in developing country markets including China, Pakistan, Hong Kong, Sri Lanka, and India. Likewise, there was an abundance of two-way volatility between the Indian stock market and Sri Lanka. Before the 2007 financial crisis, there was an abundance of volatility between Hong Kong and India, Pakistan and India, while there was an abundance of volatility between Sri Lanka and Pakistan stock markets in the post-crisis duration (Jebran et al., 2017). There is an overflow impact of unidirectional volatility between inventory expenditures and buying and selling extent earlier than the monetary crisis, and the effect of a two-way volatility spillover impact after the 2008 international monetary disaster in Turkey (Ozdemir, 2020).

\subsection{Methodology}

This empirical analysis focuses on examining the sharia index of 6 countries in ASEAN during the Covid-19 pandemic in 2020. The data used to analyze the global financial crisis was obtained from March 2, 2020, to December 31, 2020. This study analyzes the Sharia Volatility Spillovers Index in six ASEAN countries during the Covid-19 Pandemic, namely Indonesia (Jakarta Islamic), the Philippines (FTWIPHLL), Malaysia (FBMKCI), Singapore (STI), Thailand (SET), and Vietnam (VN INDEX). Data was collected from the Bloomberg database.

\subsection{Testing Stationary Data}

Statistical tests were also performed to analyze stationary data, apart from plotting time-series graphs, using the Augmented Dicky Fuller test (ADF test). Some time-series data such as price are non-stationary because there is no fixed price level. This type of series is called a unit-root non-stationary time series because it is a stochastic process capable of causing problems in time series modeling (Tsay, 2005; Mabrouk, 2020). The ADF test process is presented as follows (Brockwell \& Davis, 2002, Tsay, 2005).

$x_{1}, x_{2} \ldots, x_{n}$ are time-series data and $\{\mathrm{xt}\}$ follow the $\mathrm{AR}(\mathrm{p})$ model with mean $\mu$. The mathematical expression of the model is presented in Eq. (1).

$$
X t(\mu+\varphi 1 X t-1)=\sum_{i=1}^{p-1} \varphi 1 \Delta X t-1+\varepsilon t
$$

where $x t$ denotes the difference sequence, $\varepsilon t$ is white noise with mean 0 and the variance $\sigma 2(\varepsilon \mathrm{t} \sim \mathrm{WN}(0, \sigma 2))$. The ADF test as a unit-root test was carried out by calculating the statistical value $\tau$ as follows:

Ho: $\phi 1=1$ (non-stationary data).

Ho: $\phi 1<1$ (stationary data). Statistics.

Statistical test (ADF test):

$$
\tau=\frac{\varphi 1}{\operatorname{Se} \varphi 1}
$$

For the level of significance $(\alpha=0.05)$, Ho is rejected if $\tau<-2.57$ or if $\mathrm{P}<0.05$ (Brockwell \& Davis, 2002. P.195).

\subsection{Checking for White Noise}

Montgomery et al. (2008) stated that a time series is termed a white noise when it consists of uncorrelated observations (data) and has constant variance. Furthermore, when the observed time series is typically distributed, it is referred to as Gaussian white noise. When the time sequence is termed a white noise, the distribution of the pattern autocorrelation coefficient at lag okay in a massive pattern is shut to the everyday distribution with a suggestion of zero and a variance of $1 / \mathrm{T}$, the place $\mathrm{T}$ is the range of observations (Montgomery et al., 2008; Brockwell \& Davis, 2002; Pankratz, 1991). The expression is presented in Eq. (3).

$$
r \sim N\left(0, \frac{1}{T}\right.
$$

Based on Eq. (3), it is possible to test the autocorrelation lag k Ho: $\rho \mathrm{k}=0$ against Ha: $\rho \mathrm{k} \neq 0$ using test statistics, as in Eq. (4).

$$
Z=\frac{r k}{\sqrt{1} / T}=r k \sqrt{T}
$$

Ho is rejected if $|\mathrm{Z}|>\mathrm{Z}_{\alpha / 2}$ is the top $\alpha / 2$ percent of the standard or if $\mathrm{P}<0.05$. The test statistic given by Eq. (4) can be used to test ACF and PACF (Wei, 2006). Also, when the ACF slowly decays, the time series is indicated as non-stationary. The 
procedure presented above is carried out one test at a time with the level of significance applied to the autocorrelation and considered individually. This study aims to evaluate a set of autocorrelations simultaneously when the time series is indicated as white noise. Therefore, this problem is solved using a statistical expression given by the Box-Pierce statistic (Box-Pierce, 1970), as shown in Eq. (5)

$$
Q_{B P}=T \sum_{k=1}^{K} r^{2} \mathrm{k}
$$

It is dispensed about as chi-squared with levels of freedom $\mathrm{K}$ and below the null speculation that the time sequence is white noise (Montgomery et al., 2008). Ho is rejected if $Q_{B P}>X_{a, K}^{2}$ and concludes that the time series is not white noise. It is also possible to use the $\mathrm{p}$-value to reject Ho if $\mathrm{P}<0.05$. When the data is not stationary, the data differentiation and transformation processes are conducted.

\subsection{Testing the ARCH Effect}

This step is to estimate and examine parameters, diagnose and test residuals, and select the best model based on the criteria with the smallest value from AIC or SC. The residuals obtained from the best ARMA model are examined using the LM test to decide the $\mathrm{ARCH}$ effect. In the presence of an $\mathrm{ARCH}$ effect, the statistics have modeled the use of the $\mathrm{ARCH}$ or $\mathrm{GARCH}$ method. The sequence of the ARCH or GARCH mannequin is observed with the aid of plotting the rectangular of the PACF residuals.

\subsection{ARCH model}

The ARCH/GARCH model is based on the assumption that the variance is not constant. According to Engle (2001), this assumption is called heteroscedasticity. It is associated with the basic concept of the least-squares mannequin that assumes the predicted values of all squared blunders are identical at some point. The ARCH and GARCH fashions deal with heteroscedasticity as a variant that desires to be modeled (Engle, 2001; Bollerslev, 1986). Furthermore, Engle (1982) introduced a conditional time-variance model with an autoregressive conditional heteroscedasticity (ARCH) model using lagged disturbances. Engle (2001), (Abbady et al., 2019) stated that ARCH is an autoregression function, which assumes that the variance is not constant over time and is affected by past data. The idea behind this model is to determine the relationship between current and previous random variables.

\subsection{Generalized ARCH (GARCH) model)}

Multiple GARCH (Generalized Autoregressive Conditional Heteroscedastic) model is a general form of ARCH built to avoid high sequences. The GARCH model does not only examine the relationship between several residuals, it also depends on some past residuals (Eliyawati, 2014). GARCH was introduced by Bollerslev (1986), and the model with degrees $\mathrm{p}$ and $\mathrm{q}$ is defined as follows.

$$
X_{t}\left|F_{t-1}\right| \sim N\left(0, \sigma^{2}{ }_{t}\right)
$$

The model allows conditional variants based on the previous lag, as shown in Eq. (7).

$$
\sigma_{t}^{2}=\omega+\sum_{i=1}^{q} \lambda_{i \varepsilon_{t-i}^{2}}+\sum_{j=1}^{p} \beta_{j \sigma_{t-j}^{2}}
$$

where the present value of the conditional variant is parameterized based on the $q$ lag of the residual square and the $\mathrm{p}$ lag written as GARCH $(p, q)$. Therefore, the varied conditional variance of the GARCH model is heteroscedastic with autoregression and MA (Wang, 2009). The GARCH model is written as in Eq. (8).

$$
\begin{aligned}
& X_{t}=\delta+\sum_{i=1}^{p} \emptyset_{1} X_{t-i}-\sum_{i=1}^{q} \theta_{1} \varepsilon_{t-i}+\varepsilon_{t} \\
& \varepsilon_{t} \sim N\left(0, \sigma^{2}\right) \\
& \sigma^{2}{ }_{t}=\omega+\sum_{i=1}^{q} \lambda_{i \varepsilon_{t-i}^{2}}+\sum_{j=1}^{p} \beta_{j \sigma_{t-j}^{2}}
\end{aligned}
$$

$\mathrm{x}_{\mathrm{t}}$ is the equation of conditional mean (Bollerslev, 1986).

\subsection{EGARCH model}

This lookup makes use of the EGARCH model, additionally recognized as the GARCH-BEKK mannequin designed with the aid of (Vo \& Ellis, 2018), to manipulate the doable structural breaks in the volatility series. In particular, it makes use of the Iterative Cumulative Sum of Squares algorithm (ICSS) proposed via Inclán and Tiao (1994) to discover some lag dates in the Volatility Spillovers of Sharia Index in ASEAN all through the Covid-19 Pandemic and additionally to study its consequences on different ASEAN inventory markets. The unique ICSS algorithm was once broadly utilized in research analyzing volatility spillovers. However, only a few researchers used this method to manipulate structural injury from an 
EGARCH perspective. The ICSS algorithm wants the assumption of stationary unconditional variance over a duration separated via a detected breakpoint. This is additionally used to estimate the impact of volatility in inventory market returns. Several literature studies, such as (Kim \& Kon, 1994), (Singh \& Shukla, 2020), (Teniwut et al., 2019) stated that Nelson's (1991) EGARCH model is the most appropriate specification for modeling stock index volatility. This was further confirmed in many subsequent studies, such as the research carried out by (Krause \& Tse, 2013). After detecting all points of trade in the volatility sequence, this lookup estimates the EGARCH model, which calculates exchange factors for every sequence of ASEAN inventory returns. All factors of trade are calculated with the aid of a set of dummy variables that are assigned a fee of 1 for each factor of trade invariance and zero when otherwise. The motive for the usage of the EGARCH (1,1) mannequin as a substitute than GARCH $(1,1)$ is to loosen the non-negative constraints of the variance equation coefficient. More specifically, AR (1) -EGARCH $(1,1)$ is tailored for the collection of returns for every u. s . a . in the statistics sample. In general, the suggest and variance equations are represented as follows:

$$
\begin{aligned}
& R_{i t}=\alpha_{0 i}+\alpha_{1 i} R_{i, t-1}+\varepsilon_{i t}, \varepsilon_{i t} \sim N(0, \text { hit }), \\
& h_{i t}=\beta_{0 i}+\sum \delta_{j i} \text { Break }_{j i}+\beta_{1 i} h_{i, t-1}+\gamma \varepsilon_{2}
\end{aligned}
$$

where

$R_{i t}$ : The return of country $i$ on day $t$

$H_{i t}$ : The variance of stock returns in country $i$ on day $t$

Break: The dummy variable for the breakpoint $j$ of 1 during the period between the breaking point $(j-1)$ to the breakpoint $j$ and 0 elsewhere.

To ensure resilience, the AR (1) -EGARCH $(1,1)$ model is estimated without structural damage dummies. However, ASEAN stock market volatility is incorporated into the variance equation.

$$
R_{i t}=\alpha_{0 i}+\alpha_{1 i} R_{i, t-1}+\varepsilon_{i t}, \varepsilon_{i t} \sim N(0, h i t) ; h_{i t}=\beta_{0 i}+\theta_{i} U S V \text { olatility }+\beta_{1 i} h_{i, t-1}+\gamma \varepsilon_{2}
$$

where Volatility Spillovers is the variance of ASEAN stock returns and $\theta_{i}$ shows the effect of the stock return variance on a country $i$.

\section{Results}

Table 1 shows descriptive statistics for stock market returns with positive mean returns values for all indices. Singapore stock market has the highest probability level of 0.588 .

Table 1

Descriptive Statistics (in percentage)

\begin{tabular}{lcccc}
\hline Variable & Probability & Std. Dev. & Min & Max \\
\hline R Indonesia & 0.000 & 0.064 & 2.352 & 2.907 \\
R_Philippines & 0.000 & 0.062 & -0.257 & 0.278 \\
R_Malaysia & 0.000 & 0.036 & 0.659 & 0.893 \\
R_Singapore & 0.588 & 0.028 & 2.471 & 2.611 \\
R_Thailand & 0.369 & 0.027 & 2.031 & 2.155 \\
R_Vietnam & 0.000 & 0.062 & 2.699 & 3.052 \\
\hline
\end{tabular}

The stock market daily average return in the sample is relatively large at 2.611 , while the standard deviation is smaller at 0.028. Furthermore, the stock market of several emerging markets, such as, Thailand is second after Singapore, which has a high probability of 0.369 with a standard deviation of 0.027 . Meanwhile, the other 4 countries are under Singapore and Thailand with a probability level of 0.000 .

Table 2

Unit Root Test

\begin{tabular}{cccc}
\hline Variable & Missing Points & Test statistics & Phillip - Perron \\
\hline R_Indonesia & 9 & $-11,858 * * *$ & $0,000 * * *$ \\
R_Philippines & 6 & $-14,943 * * *$ & $0,000 * * *$ \\
R_Malaysia & 7 & $-5,413 * * *$ & $0,000 * * *$ \\
R_Singapore & 5 & $-2,068 * * *$ & $0,258 * * *$ \\
R_Thailand & 4 & $-2,273 * * *$ & $0,182 * * *$ \\
R_Vietnam & 6 & $-7,856 * * *$ & $0,000 * * *$ \\
\hline$* *, * *, *$ respectively indicating a significance level of $1 \%, 5 \%$, and $10 \%$ &
\end{tabular}

The results of the stationarity test, which used the ADF and Phillip-Perron checks to decide the stationarity, are proven in Table two Both assessments rejected the null speculation of non-stationary quotes for all countries' inventory returns, indicating a regular conclusion that all inventory returns are I (0). Subsequently, white noise was performed, which is a statistical test of the estimation of the hypothesis that there is no autocorrelation from the series to a certain interval that is significantly different from zero. There is no information on the series for all logs. Autocorrelation was examined in six groups, as shown in Table 3 , in which the white noise hypothesis was strongly received $(\mathrm{P}>0.0001)$. 
Table 3

White Noise Test

\begin{tabular}{|c|c|c|c|c|c|}
\hline To Lag & P-Value & $\mathbf{A C}$ & Pac & Q-Stat & prob \\
\hline 1 & $<0,0001$ & 0.298 & 0.298 & 17.902 & 0.000 \\
\hline 2 & $<0,0001$ & 0.232 & 0.157 & 28.836 & 0.000 \\
\hline 3 & $<0,0001$ & 0.449 & 0.387 & 70.038 & 0.000 \\
\hline 4 & $<0,0001$ & 0.290 & 0.100 & 87.334 & 0.000 \\
\hline 5 & $<0,0001$ & 0.257 & 0.098 & 100.94 & 0.000 \\
\hline 6 & $<0,0001$ & 0.241 & -0.017 & 112.99 & 0.000 \\
\hline 7 & $<0,0001$ & 0.167 & -0.050 & 118.78 & 0.000 \\
\hline 8 & $<0,0001$ & 0.188 & 0.005 & 126.17 & 0.000 \\
\hline 9 & $<0,0001$ & 0.076 & -0.116 & 127.39 & 0.000 \\
\hline 10 & $<0,0001$ & 0.116 & 0.033 & 130.21 & 0.000 \\
\hline 11 & $<0,0001$ & 0.174 & 0.082 & 136.67 & 0.000 \\
\hline 12 & $<0,0001$ & 0.128 & 0.100 & 140.15 & 0.000 \\
\hline 13 & $<0,0001$ & 0.036 & -0.064 & 140.44 & 0.000 \\
\hline 14 & $<0,0001$ & 0.053 & -0.057 & 141.05 & 0.000 \\
\hline 15 & $<0,0001$ & 0.232 & 0.191 & 152.76 & 0.000 \\
\hline 16 & $<0,0001$ & 0.155 & 0.084 & 158.02 & 0.000 \\
\hline 17 & $<0,0001$ & 0.034 & -0.047 & 158.29 & 0.000 \\
\hline 18 & $<0,0001$ & 0.239 & 0.119 & 170.88 & 0.000 \\
\hline 19 & $<0,0001$ & 0.120 & -0.069 & 174.08 & 0.000 \\
\hline 20 & $<0,0001$ & 0.046 & -0.058 & 174.55 & 0.000 \\
\hline 21 & $<0,0001$ & 0.167 & 0.003 & 180.84 & 0.000 \\
\hline 22 & $<0,0001$ & 0.128 & 0.019 & 184.52 & 0.000 \\
\hline 23 & $<0,0001$ & 0.120 & 0.048 & 187.81 & 0.000 \\
\hline 24 & $<0,0001$ & -0.008 & -0.146 & 187.83 & 0.000 \\
\hline 25 & $<0,0001$ & 0.005 & -0.031 & 187.84 & 0.000 \\
\hline 26 & $<0,0001$ & 0.078 & -0.046 & 189.23 & 0.000 \\
\hline 27 & $<0,0001$ & 0.051 & 0.071 & 189.84 & 0.000 \\
\hline 28 & $<0,0001$ & -0.029 & -0.015 & 190.04 & 0.000 \\
\hline 29 & $<0,0001$ & 0.047 & 0.082 & 190.56 & 0.000 \\
\hline 30 & $<0,0001$ & 0.006 & -0.051 & 190.56 & 0.000 \\
\hline 31 & $<0,0001$ & -0.020 & -0.032 & 190.66 & 0.000 \\
\hline 32 & $<0,0001$ & 0.063 & 0.098 & 191.60 & 0.000 \\
\hline 33 & $<0,0001$ & 0.030 & -0.074 & 191.82 & 0.000 \\
\hline 34 & $<0,0001$ & 0.058 & 0.059 & 192.65 & 0.000 \\
\hline 35 & $<0,0001$ & 0.007 & -0.017 & 192.66 & 0.000 \\
\hline 36 & $<0,0001$ & -0.000 & -0.025 & 192.66 & 0.000 \\
\hline
\end{tabular}

Furthermore, testing was carried out regarding the heteroscedasticity of the Sharia Index during the Covid-19 Pandemic in ASEAN using the heteroscedasticity test with ARCH, as shown in Table 4.

Table 4

Heteroscedasticity test

\begin{tabular}{llll}
\hline F-statistic & 174.2866 & Prob. F(1,196) & 0.0000 \\
Obs*R-squared & 93.19469 & Prob. Chi-Square(1) & 0.0000 \\
\hline
\end{tabular}

The heteroscedasticity test results with ARCH show that the p-value Obs $\times \mathrm{R}$-squared $=$ zero $<\alpha$, therefore, heteroscedasticity and modeling can be endured with EGARCH to create forecasting models. Table four suggests a mannequin from EGARCH.
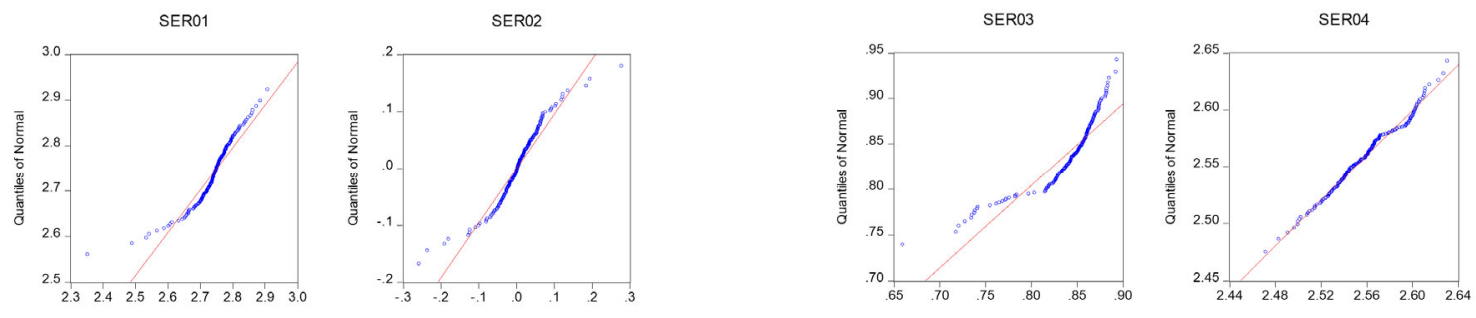

Quantles of SER01
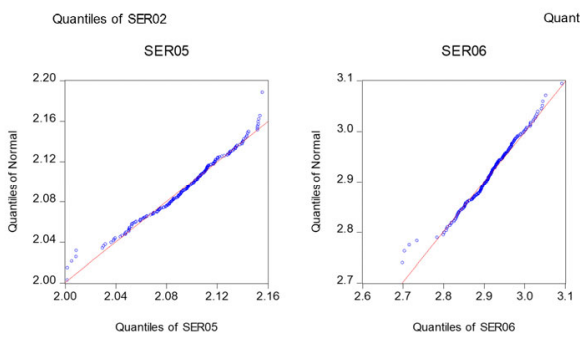

Fig. 1. Decrease of volatility spillovers in returns on Sharia Index stocks in ASEAN 
After applying white noise to pick out surprising shifts in the volatility of the sequence of returns on Islamic inventory indices in ASEAN, the EGARCH mannequin $(1,1)$ used to be estimated with and except dummy variables to analyze the overflow. The magnitude of the Break dummy variable in every EGARCH mannequin lets in estimating modifications in the related volatility and analyzes the abundance of volatility between ASEAN international locations. Table 5 shows the estimation results for the EGARCH model without considering structural damage.

Table 5

Results of the EGARC $\mathrm{H}$ model without considering structural damage $\mathrm{LOG}(\mathrm{GARCH})=\mathrm{C}(7)+\mathrm{C}(8) * \mathrm{RESID}(-1) / @ \mathrm{SQRT}(\mathrm{GARCH}(-1))+\mathrm{C}(9) * \mathrm{LOG}(\mathrm{GARCH}(-1))$

\begin{tabular}{|c|c|c|c|c|}
\hline Variable & Coefficient & Std. Error & z-Statistic & Prob. \\
\hline Indonesia & 0.045508 & 0.005669 & 8.028236 & 0.0000 \\
\hline Philippines & -0.002412 & 0.006671 & -0.361596 & 0.7177 \\
\hline Malaysia & -0.057870 & 0.013994 & -4.135359 & 0.0000 \\
\hline Singapore & 0.199745 & 0.018245 & 10.94819 & 0.0000 \\
\hline Thailand & 0.161549 & 0.023083 & 6.998642 & 0.0000 \\
\hline \multirow[t]{2}{*}{ Vietnam } & 0.027514 & 0.010517 & 2.616042 & 0.0089 \\
\hline & Variance Eq & & & \\
\hline $\mathrm{C}(7)$ & -0.517911 & 0.210506 & -2.460316 & 0.0139 \\
\hline $\mathrm{C}(8)$ & -0.080755 & 0.028914 & -2.792962 & 0.0052 \\
\hline $\mathrm{C}(9)$ & 0.949578 & 0.022101 & 42.96543 & 0.0000 \\
\hline Mean dependent var & 1.000000 & \multicolumn{2}{|c|}{ S.D. dependent var } & 0.000000 \\
\hline S.E. of regression & 0.012760 & \multicolumn{2}{|c|}{ Akaike info criterion } & -6.479688 \\
\hline Sum squared resid & 0.031425 & \multicolumn{2}{|c|}{ Schwarz criterion } & -6.330744 \\
\hline Log-likelihood & 653.7289 & \multicolumn{2}{|c|}{ Hannan-Quinn criteria. } & -6.419406 \\
\hline Durbin-Watson stat & 0.124915 & & & \\
\hline
\end{tabular}

The results in Table 5 show that the EGARCH Model indicates that Indonesia, Malaysia, Singapore, Thailand, and Vietnam have a probability of $\mathrm{R}=0.000000<\alpha$, therefore $\mathrm{H} 0$ is rejected, which means that there is spillover volatility. The results of the analysis with EGARCH nevertheless want to be re-evaluated by using carrying out quite a few tests, such as serial correlation, ARCH effect, and normality. In conclusion, the EGARCH mannequin did now not have an autocorrelation and $\mathrm{ARCH}$ effect, irrespective of whether or not the information has been no longer typically dispensed.

Table 6

Granger causality test results

Pairwise Granger Causality Tests

\begin{tabular}{|c|c|c|c|}
\hline Null Hypothesis: & Obs & F-Statistic & Prob. \\
\hline The Philippines Does Not Granger Cause Indonesia & 197 & 0.96975 & 0.381 \\
\hline Indonesia Does Not Granger Cause Philippines & & 2.30871 & 0.1021 \\
\hline Malaysia Does Not Granger Cause Indonesia & 197 & 2.81186 & 0.0626 \\
\hline Indonesia Does Not Granger Cause Malaysia & & 1.19861 & 0.3039 \\
\hline Singapore Does Not Granger Cause Indonesia & 197 & 4.12609 & 0.0176 \\
\hline Indonesia Does Not Granger Cause Singapore & & 0.50001 & 0.6073 \\
\hline Thailand Does Not Granger Cause Indonesia & 197 & 1.68209 & 0.1887 \\
\hline Indonesia Does Not Granger Cause Thailand & & 1.49094 & 0.2278 \\
\hline Vietnam Does Not Granger Cause Indonesia & 197 & 2.57696 & 0.0786 \\
\hline Indonesia Does Not Granger Cause Vietnam & & 0.33952 & 0.7125 \\
\hline Malaysia Does Not Granger Cause Philippines & 201 & 6.14871 & 0.0026 \\
\hline The Philippines Does Not Granger Cause Malaysia & & 20.0764 & $1.00 \mathrm{E}-08$ \\
\hline Singapura Does Not Granger Cause Philippines & 201 & 1.58846 & 0.2069 \\
\hline The Philippines Does Not Granger Cause Singapura & & 7.50724 & 0.0007 \\
\hline Thailand Does Not Granger Cause Philippines & 201 & 3.65236 & 0.0277 \\
\hline The Philippines Does Not Granger Cause Thailand & & 3.84320 & 0.0231 \\
\hline Vietnam Does Not Granger Cause Philippines & 201 & 4.52835 & 0.012 \\
\hline The Philippines Does Not Granger Cause Vietnam & & 0.55620 & 0.5743 \\
\hline Singapore Does Not Granger Cause Malaysia & 202 & 0.81665 & 0.4434 \\
\hline Malaysia Does Not Granger Cause Singapore & & 0.14946 & 0.8613 \\
\hline Thailand Does Not Granger Cause Malaysia & 205 & 0.19914 & 0.8196 \\
\hline Malaysia Does Not Granger Cause Thailand & & 3.02540 & 0.0508 \\
\hline Vietnam Does Not Granger Cause Malaysia & 205 & 3.54464 & 0.0307 \\
\hline Malaysia Does Not Granger Cause Vietnam & & 8.58959 & 0.0003 \\
\hline Thailand Does Not Granger Cause Singapore & 202 & 2.40613 & 0.0928 \\
\hline Singapore Does Not Granger Cause Thailand & & 0.21592 & 0.806 \\
\hline Vietnam Does Not Granger Cause Singapore & 202 & 3.66561 & 0.0273 \\
\hline Singapore Does Not Granger Cause Vietnam & & 2.68597 & 0.0707 \\
\hline Vietnam Does Not Granger Cause Thailand & 213 & 4.69750 & 0.0101 \\
\hline Thailand Does Not Granger Cause Vietnam & & 0.76150 & 0.4683 \\
\hline
\end{tabular}


In this study, the Granger causality takes a look at what used to be carried out to decide whether or not the volatility spillover variable and the Sharia Index variable had a unidirectional, two-way, or no causality relationship the usage of facts from 1247 days of observation. Table 6 suggests the effects of the Granger causality take a look at the return volatility spillover on the Sharia Index of 6 ASEAN international locations.

\section{Discussion}

The effects confirmed that there was once a volatility spillover extending in the worldwide monetary integration of the Islamic index of 6 international locations in ASEAN as indicated by using the EGARCH method. Furthermore, the granger causality takes a look at was once carried out to decide the route of volatility spillover, which was once determined to have no relationship in the inventory markets of Indonesia, Malaysia, Singapore, Thailand, and Vietnam barring for the Philippines and the Sharia Index at some stage in the Covid-19 Pandemic in ASEAN. Therefore, this suggests that shocks in the inventory markets of Indonesia, Malaysia, Singapore, Thailand, and Vietnam, have been now not accountable for shocks in the Sharia Index for the duration of the Covid-19 Pandemic in ASEAN and vice versa. Globalization and economic liberalization facilitate the motion of capital throughout borders. This style additionally encourages volatility spillover from mature to rising markets. These findings are integral for buyers in portfolio funding and chance management. It is additionally applicable for policymakers to embed the applicable framework for monitoring and controlling immoderate volatility spillovers.

\section{Conclusion}

Emerging markets grant the best place for analyzing inventory market volatility for numerous reasons. It is commonly identified that rising markets are extra unstable than developed fairness markets. This risky nature is exaggerated by way of the reality that rising fairness markets are small and closely influenced through small improvements in developed markets. Therefore, this finds out investigates the Volatility Spillovers of Sharia Index in the course of the Covid-19 Pandemic in ASEAN. Data on the Volatility Spillovers of Sharia Index facts throughout the Covid-19 Pandemic in ASEAN had been acquired from March two - December 31, 2020.

\section{References}

Abbady, M. A. S., Akkaya, M., \& Sari, A. (2019). Big data governance, dynamic capability and decision-making effectiveness: Fuzzy sets approach. Decision Science Letters, 8(4), 429-440. https://doi.org/10.5267/j.ds1.2019.5.003

Aggarwal, R., Inclan, C., \& Leal, R. (1999). Volatility in Emerging Stock Markets. The Journal of Financial and Quantitative Analysis, 34(1), 33. https://doi.org/10.2307/2676245

Arfah, A., Olilingo, F. Z., Syaifuddin, S., Dahliah, D., Nurmiati, N., \& Putra, A. H. P. K. (2020). Economics During Global Recession: Sharia-Economics as a Post COVID-19 Agenda. Journal of Asian Finance, Economics, and Business, 7(11), $1077-1085$. https://doi.org/10.13106/jafeb.2020.vol7.no11.1077

Batten, J. A., Kinateder, H., Szilagyi, P. G., \& Wagner, N. F. (2019). Liquidity, surprise volume, and return premia in the oil market. Energy Economics, 77, 93-104. https://doi.org/10.1016/j.eneco.2018.06.016

Billio, M., Donadelli, M., Paradiso, A., \& Riedel, M. (2017). Which market integration measure? Journal of Banking and Finance, 76, 150-174. https://doi.org/10.1016/j.jbankfin.2016.12.002

Carrieri, F., Errunza, V., \& Hogan, K. (2007). Characterizing world market integration through time. Journal of Financial and Quantitative Analysis, 42(4), 915-940. https://doi.org/10.1017/s0022109000003446

Dean, W. G., Faff, R. W., \& Loudon, G. F. (2010). Asymmetry in return and volatility spillover between equity and bond markets in Australia. Pacific-Basin finance journal, 18(3), 272-289. https://doi.org/10.1016/j.pacfin.2009.09.003

Diebold Kamil Yilmaz, F. X., Binder, M., Dominguez, K., Frankel, J., Giavazzi, F., Leeper, E., Reichlin, L., West, K., Diebold, F. X., \& Yilmaz, K. (2008). NBER Working Paper Series Measuring Financial Asset Return and Volatility Spillovers, With Application To Global Equity Markets. 119, 158-171. http://www.nber.org/papers/w13811

Gunarto, T., Azhar, R., Tresiana, N., Supriyanto, \& Ahadiat, A. (2020). An accurate estimated model of volatility crude oil price. International Journal of Energy Economics and Policy, 10(5), 228-233. https://doi.org/10.32479/ijeep.9513

John Wei, K. C., Liu, Y. J., Yang, C. C., \& Chaung, G. S. (1995). Volatility and price change spillover effects across the developed and emerging markets. Pacific-Basin Finance Journal, 3(1), 113-136. https://doi.org/10.1016/0927-538X(94)00029-7

Kim, D., \& Kon, S. J. (1994). Alternative Models for the Conditional Heteroscedasticity of Stock Returns. The Journal of Business, 67(4), 563. https://doi.org/10.1086/296647

Krause, T., \& Tse, Y. (2013). Volatility and return spillovers in Canadian and U.S. industry ETFs. International Review of Economics and Finance, 25, 244-259. https://doi.org/10.1016/j.iref.2012.07.009

Levent, S., \& Beliz, O. (2020). Investing in gold or REIT index in Turkey: evidence from the global financial crisis, 2018 Turkish currency crisis, and COVID-19 crisis. In Journal of European Real Estate Research: Vol. ahead-of-print (Issue ahead-of-print). https://doi.org/10.1108/JERER-04-2020-0023.

Mabrouk, N. Ben. (2020). Green supplier selection using fuzzy Delphi method for developing the sustainable supply chain. Decision Science Letters, 10(1), 63-70. https://doi.org/10.5267/j.ds1.2020.10.003

Mahata, A., Rai, A., Prakash, O., \& Nurujjaman, M. (2020). Modeling and analysis of the effect of Covid-19 on the stock price: v and 1-shape recovery. ArXiv, Die. 
Milunovich, G., \& Thorp, S. (2006). Valuing volatility spillovers. Global Finance Journal, 17(1), 1-22. https://doi.org/10.1016/j.gfj.2006.06.007

Miyakoshi, T. (2003). Spillovers of stock return volatility to Asian equity markets from Japan and the US. Journal of International Financial Markets, Institutions, and Money, 13(4), 383-399. https://doi.org/10.1016/S1042-4431(03)00015-5

Nelson. (1991). Conditional Heteroskedasticity in Asset Returns A New Approach Author ( s ): Daniel B. Nelson Published by The Econometric Society Stable URL : http://www.jstor.org/stable/2938260. Conditional heteroskedasticity in asset returns: a new approach. Society, 59(2), 347-370.

Nikmanesh, L., \& Mohd Nor, A. H. S. (2016). Macroeconomic determinants of stock market volatility: An empirical study of Malaysia and Indonesia. Asian Academy of Management Journal, 21(1), 161-180.

Sharma, P. (2021). Energy-efficient target set selection and buffer management for d2d mobile data offloading. International Journal of Data and Network Science, 5(1), 1-10. https://doi.org/10.5267/j.ijdns.2020.12.002

Singh, D., \& Shukla, R. (2020). Multi-objective optimization of selected non-traditional machining processes using Asia-ii. Decision Science Letters, 9(3), 421-438. https://doi.org/10.5267/j.ds1.2020.3.003

Suripto, S. (2021a). Characteristics of banks as determinants of profit management for Islamic and conventional banks in ASEAN. Accounting, 7, 1179-1188. https://doi.org/10.5267/j.ac.2021.2.020

Suripto, S. (2021b). The Effect of the COVID-19 Pandemic on Stock Prices with the Event Window Approach : A Case Study of State Gas Companies, in the Energy Sector. International Journal of Energy Economics and Policy, 11(3), $155-162$. https://www.econjournals.com/index.php/ijeep/article/view/10999/5799

Teniwut, W. A., Hamid, S. K., \& Makailipessy, M. M. (2019). Selecting top fisheries sub-sector in each sub-district for sustainable development of the archipelagic region in Indonesia: A hybrid fuzzy-MCDM approach. Decision Science Letters, 8(4), 393410. https://doi.org/10.5267/j.ds1.2019.6.001

Tiao, G. C., \& Inclan, C. (2010). Use of Cumulative Sums of Squares for Retrospective Detection of Changes of Variance. Journal of the American Statistical Association, 89(427), 913-923.

Vo, X. V., \& Ellis, C. (2018). PT CR. 2017, \#pagerange\#. https://doi.org/10.1016/j.ememar.2018.03.007 


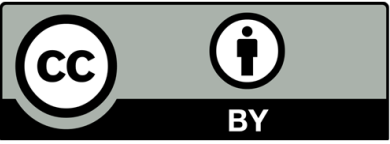

(C) 2021 by the authors; licensee Growing Science, Canada. This is an open access article distributed under the terms and conditions of the Creative Commons Attribution (CC-BY) license (http://creativecommons.org/licenses/by/4.0/). 